\title{
Yhteiskuntatieteiden mielellinen käänne
}

\author{
Gronow, Antti \& Tuukka Kaidesoja (toim.) 2017: Ihmismielen sosiaalisuus. \\ Helsinki: Gaudeamus. 267 sivua.
}

\author{
Konsta Kajander
}

\begin{abstract}
A kuun lämmittelykysymys. Mikä teoreettinen lähestymistapa yhdistää seuraavia tutkijoita: Naomi Quinn, Roy D'Andrade, Anna-Leena Siikala, Seppo Knuuttila, Veikko Anttonen ja Ilkka Pyysiäinen? Jos kaksi ensiksi mainittua antropologia kuulostavat vielä vierailta, seuraavana tulevat kotimaiset folkloristit ja uskontotieteilijät lienevät tuttuja useimmille Eloren lukijoille. Vastaus on tietenkin kognitiivinen lähestymistapa, jossa kulttuuria ja perinnettä lähestytään ihmismielen, ajattelun ja tiedon sisältöjen kautta. Suomalaisessa folkloristiikassa kognitiivisen tutkimuksen työkaluja kuten skeemateoriaa alettiin hyödyntää viimeistään 1980-luvulla (Siikala 1984; Kaivola-Bregenhøj 1988), ja 1990-luvun uskontotieteessä on puhuttu suorastaan kognitiivisesta käänteestä. Sen sijaan naapuritiede etnologiaan kognitiivinen suuntaus on rantautunut heikosti. Tarkka syy tähän ei ole tiedossa. Kenties lähestymistavan naturalistinen pohjavire ja kulttuurin selittäminen (osin) psykologisilla tekijöillä ovat tehneet siitä luotaantyöntävän hermeneuttiselle ja emansipatoriselle nykyetnologialle.

Antti Gronowin ja Tuukka Kaidesojan toimittaman Ihmismielen sosiaalisuus -artikkelikokoelman (2017) perusteella kognitiivinen lähestymistapa näyttää herättäneen kiinnostusta myös suomalaisissa yhteiskuntatieteissä. Teos koostuu yhdeksästä artikkelista, joiden kirjoittajat edustavat sosiologiaa, neuro-, talous- ja kasvatustiedettä, sosiaalipsykologiaa ja filosofiaa. Vaikka teoksen ensisijaisena kohderyhmänä ovat yhteiskuntatieteilijät ja alan opiskelijat, myös kulttuurintutkijoiden kannattaa tarttua tähän (kirjaimellisesti!) mielenkiintoiseen kirjaan. Antropologian vanhemmista klassikoista viittauksia saavat Lucien Lévy-Bruhl, Gregory Bateson ja Marcel Mauss, kognitiivisen antropologian klassikoille Dan Sperberille ja Edwin Hutchinsille puolestaan omistetaan omat artikkelit. Kulttuuri saa siis kokoelmassa runsaasti tilaa.
\end{abstract}

\section{"Bridge Over Troubled Water"}

Teoksella on kolme tavoitetta: se pyrkii rakentamaan siltaa kognitiotieteiden ja yhteiskuntatieteiden välille, haastamaan ihmismielen tutkimuksen individualistista lähestymistapaa sekä kannustamaan yhteiskuntatieteilijöitä ottamaan ihmismieli vakavasti. Kirjan kaksi ensimmäistä lukua antavat lukijalle pohjatietoja mielen evoluutiosta ja aivotutkimuksesta, 
jonka jälkeen mieltä lähestytään sosiologisesta, antropologisesta, sosiaalipsykologisesta, taloustieteellisestä ja filosofisesta näkökulmasta.

Aluksi sosiologit Antti Gronow ja Tuukka Kaidesoja esittelevät johdantoartikkelissaan ihmismielen evolutiivista perustaa koskevia teorioita. Artikkelin myötä käy ilmeiseksi, ettei ihmismieli ole syntyessään tabula rasa, vaan oppimiselle, altruismille ja kyvylle tehdä erotteluita sisä- ja ulkoryhmien välillä on jo olemassa biologisen ja kulttuurisen evoluution kuluessa kehittyneet sisäsyntyiset kognitiiviset valmiudet. Gronowin ja Kaidesojan mukaan esimerkiksi rasismi ei pohjaudu pelkkiin (modernien länsimaiden) kulttuurisiin ajattelutottumuksiin, vaan taustalla on ryhmäsamaistumiseen liittyviä tiedostamattomia tunnereaktioita, joiden evolutiivisen ja sosiaalipsykologisen pohjan tunteminen auttaa samalla ilmiötä vastaan taistelemisessa. Kiinnostavista lähtökohdistaan huolimatta artikkeli jää harmittavan lyhyeksi. Epäselväksi jää, miten evolutiivisen näkökulman tulisi käytännössä näkyä yhteiskuntatieteellisissä tutkimusaiheissa, hypoteeseissa tai metodeissa. Ensimmäinen "sillanrakennus" nähdään oikeastaan johdannon jälkeisessä artikkelissa, jossa neurotieteilijä Rita Hari suosittelee alansa tutkijoita tutustumaan Erving Goffmaniin ja testaamaan hänen sosiaalista vuorovaikutusta koskevaa teoriaansa geokätköilyllä.

Yksi teoksen avainartikkeleista on sosiologien Anssi Peräkylän ja Antti Gronowin "Ihmismieli ja sosiaalinen vuorovaikutus", jossa esitellään konstruktionistinen mielen sosiologinen tutkimussuuntaus. Artikkelin myötä sosiologian jännitteinen suhde kognitiiviseen tutkimukseen käy ymmärrettäväksi. Jo Emilé Durkheimin muotoilema metodologinen periaate yhteiskunnallisten ilmiöiden selittämisestä yhteiskunnallisilla seikoilla sulkee lähtökohtaisesti psykologiset selitykset sosiologian ulkopuolelle. Toisaalta Durkheimilla oli tuotannossaan viittauksia ihmismieleen, samoin toisella sosiologian klassikolla Max Weberillä. Myöhemmin teoksen sosiaalipsykologiaa käsittelevästä artikkelista käy ilmi, että Durkheimin ja Marcel Maussin käyttämällä kollektiivisten representaatioiden käsitteellä oli suuri merkitys Serge Moscovicin sosiaalisten representaatioiden teorialle.

Konstruktionistinen mielen sosiologia perustuu sosiaalisen konstruktionismin ja diskursiivisen psykologian lähtökohdille. Siinä mieltä, tietoa, tunteita ja intentioita tutkitaan keskusteluanalyyttisin menetelmin osana toimijoiden vuorovaikutustilanteita. Yhteiskunta- ja kognitiotieteiden yhteistyön kannalta lähestymistapa on ongelmallinen, sillä toimijoiden sisäiset mielelliset tilat ja prosessit eivät voi toimia toiminnan selityksenä. Peräkylä \& Gronow kritisoivat konstruktionismia itse mielen ja mieltä koskevien käsitysten erottamisesta, ja korostavat sen sijaan ihmismielen ja sosiaalisen vuorovaikutuksen yhteenkuuluvuutta. He ehdottavat lähestymistavan laajentamista kahdella tutkimusohjelmalla. Mielenluennan mikrososiologia ottaa sosiaalista vuorovaikutusta koskevissa selityksissä huomioon kehityspsykologisen mielen teorian, jonka mukaan ihmisillä on luontainen kyky ymmärtää paitsi omia myös muiden sisäisiä tiloja kuten haluja, uskomuksia ja intentioita. Teoriaa täydentää systeeminen näkemys tunteiden säätelystä, joka huomioi lisäksi vuorovaikutuksessa ilmenevät ei-sanalliset viestit kuten kasvojen ilmeet ja psykofysiologiset tilat kuten sydämen lyöntitiheyden. Näiden kahden lähestymistavan avulla, sekä keskusteluanalyyttisiä ja psykofysiologisia menetelmiä yhdistämällä, toimijoiden välisessä vuorovaikutuksessa ilmenevää mielenluentaa eli toisten ihmisten kognition, intentioiden ja affektien tulkintaa voidaan tutkia osana erilaisia vuorovaikutuskäytänteitä kuten terveydenhuoltoa, kasvatusta tai markkinointia. 
Vaikka kirjassa osoitetaan hyvin ihmismielen sosiaalinen luonne samoin kuin sosio-kulttuuristen olosuhteiden huomioimisen tärkeys kognition tutkimuksessa, en ole varma, saadaanko myös yhteiskuntatieteiden opiskelijat vakuuttumaan kognitiivisen lähestymistavan mahdollisuuksista. Teosta käyttävien opettajien onkin hyvä pohtia, mitä lisäarvoa näkökulma voi tuoda esimerkiksi sellaisten yhteiskunnallisesti tärkeiden tutkimuskohteiden kuten maahanmuuton, terveyden ja hyvinvoinnin, ympäristökysymysten, työttömyyden tai syrjäytymisen tutkimiseen. Tällaisten konkreettisten esimerkkien lisäksi olisin kaivannut artikkelikokoelmalta keskustelua kognitiivisen ja sosiologisen tutkimuksen yhteyksiä käsitelleiden tutkijoiden kuten Paul DiMaggion, Karen A. Cerulon, Wayne Brekhusin, Eviatar Zerubavelin tai Rogers Brubakerin kanssa. Näistä Brubakerin kategorioita ja ryhmän muodostumisen prosesseja painottava tutkimusote vaikuttaa hedelmälliseltä etenkin etnisyydestä kiinnostuneille tutkijoille (ks. Fingerroos 2014).

\section{Näkökulmia (mielettömään) kulttuuriin}

Alun pienen, mutta tärkeän sivuroolin jälkeen kulttuuri nousee pääestradille kirjan neljännessä ja kuudennessa artikkelissa. Antti Gronow esittelee ensin kognitiivista antropologiaa edustavan Dan Sperberin (1996) teorian representaatioiden epidemiologiasta. Teorian mukaan kulttuuriset ideat leviävät ikään kuin viruksen tavoin mentaalisina representaationa yksilöiltä toiselle. Mikäli representaatiot ketjuuntuvat ja yleistyvät populaation sisällä, voidaan puhua kulttuurisista representaatioista. On huomattava, että naturalistisesta pohjasta huolimatta näkemys jättää tilaa kulttuurintutkimukselle tärkeille merkityksille. Vaikka yksilöt tulkitsevat kulttuurisia representaatioita sisäisten mentaalisten mallien avulla, joita ei voi sinänsä havaita, merkitykset leviävät kulttuurissa intersubjektiivisesti julkisten representaatioiden kautta. Esimerkiksi "Suomi" voi saada ilmauksen artefakteissa (siniristilippu), rituaaleissa (itsenäisyyspäivä) tai ääniaalloissa (Maamme-laulu). Tällaiset representaatiot eivät silti itsessään olisi merkityksellisiä elleivät kulttuurin jäsenet muodostaisi niihin merkityksellistä suhdetta ja välittäisi niitä eteenpäin tuleville sukupolville.

Gronow nostaa aiheellisesti esiin teorian ongelman: miten kulttuuriset representaatiot oikeastaan leviävät ja miten tätä leviämistä voisi tutkia? Hän tarjoaa teorian täydennykseksi yhteiskuntatieteellistä verkostoanalyysiä. Tällöin huomio voidaan kiinnittää siihen, miten kulttuuriset ideat leviävät esimerkiksi yksittäisten toimijoiden, medioiden tai organisaatioiden välityksellä. Verkostoanalyysi vaikuttaakin lupaavalta menetelmältä erityisesti uusien kulttuuristen ideoiden leviämisen tutkimuksessa. Haluan kuitenkin tässä yhteydessä nostaa esiin myös kolikon kääntöpuolen eli miksi kulttuuri ei leviä? Tanskalainen uskontotieteilijä Jesper Sørensen on esittänyt kiinnostavan teorian "kulttuuristen järjestelmien immunologiasta". Sen mukaan yhteisöissä vallitsevilla kulttuurisilla malleilla on itseään suojelevia vaikutuksia, jotka estävät uusien ideoiden leviämisen populaatiossa. (Sørensen 2011, 190-193.) Jotta uudet ideat voisivat levitä, niiden on ensin muutettava jo olemassa olevia ajattelu- ja toimintamalleja tai sulauduttava niihin. Tämä on tärkeä huomioida esimerkiksi uutuuksien, modernisaation tai digitalisaation tutkimuksessa.

Toinen kulttuurintutkijoiden kannalta keskeinen artikkeli on sosiologi Tuukka Kaidesojan ja kasvatustieteilijä Sami Paavolan kirjoittama "Ympäristöön hajautunut kognitio", jonka pääosassa on Edwin Hutchins, kognitiivisen etnografian urauurtaja. Lähestymistavassa kognitiivista toimintaa havainnoidaan luonnollisissa ympäristöissä laboratoriossa järjestettyjen koeolosuhteiden sijaan. Klassikkotutkimuksessaan Cognition in the Wild (1995) Hutchins 
seurasi Yhdysvaltain armeijan maihinnousualuksen navigointia etnografisin menetelmin, osallistuvan havainnoinnin, haastattelujen, ääninauhoitusten ja videoinnin keinoin. Tutkimuksen keskeinen tulos oli, ettei aluksen navigointi haastavilla kulkuväylillä olisi onnistunut ilman toiminnan hajauttamista pienempiin osatekijöihin. Aluksen tiimissä navigointiin liittyneet tehtävät jakaantuivat vastaavan upseerin, kolmen tähystäjän ja "piirturin" kesken. Hutchinsin havainnoimaan kokonaisuuteen kuului miehistön lisäksi materiaalinen toimintaympäristö (laivan komentokansi) sekä artefaktit (merikortti, kaukoputki, kompassi, radiopuhelin). Lisäksi Hutchins vertaili aluksen toimintaa mikronesialaisiin navigointikäytäntöihin, jossa sama kognitiivinen tehtävä suoritettiin "tähtipoluista" muodostuneilla kulttuurisilla representaatioilla yhdysvaltalaisten "paikannussyklien" sijasta. Kaidesojan ja Paavolan mukaan lähestymistavan etuna on, että se mahdollistaa inhimillisen kognition monipuolisen tutkimisen sekä osana sosiaalista ja kehollista toimintaa että sosiokulttuurisia ja materiaalisia olosuhteita.

Viimeistään tämän artikkelin kohdalla pitäisi olla selvää, ettei ihmismielestä kiinnostuneiden (kulttuurin)tutkijoiden tarvitse rynnätä heti aivotutkimuskeskukseen. Esimerkiksi sellaiset etnologeille tärkeät tutkimusaiheet kuten etnisyys, sukupuoli, mentaliteetit, maailmankuvat, muisti ja kerronta sekä ylipäätään kulttuurien kohtaamiseen ja arkielämään liittyvät toiminta- ja ajattelutavat sisältävät kognitiivisen ulottuvuuden, jota voidaan tutkia yhtä hyvin etnografisin menetelmin saadun havaintoaineiston, haastattelu- kuin tekstiaineistojenkin perusteella (vrt. Bloch 2012).

\section{Tukeva brunssi maittavaa päivällistä odotellessa}

Miten teos onnistui tavoitteissaan? Joko silta kognitiotieteiden ja yhteiskuntatieteiden välillä on niin tukevalla pohjalla että tieteitä halkovan "synkän virran" uskaltaisi ylittää? Sosiaalipsykologiassa yhteys on jo olemassa, mutta taloustieteen ja sosiologian kannalta yhteistyö voi osoittautua hankalammaksi, varsinkin jos niiden tutkimuskohteet nähdään omalakisina järjestelminä, joista mieleen viittaavat selitykset suljetaan pois. Mutta kannustuksesta sillan rakennus ei jää kiinni. Kirjan päätösartikkelissa filosofi Petri Ylikoski toteaakin rohkaisevasti, ettei ihmismieli ole "psykologien yksityisomaisuutta", vaan mielen sosiaalisuuden myötä myös "yhteiskuntatieteilijöillä on sanansa sanottavana" (s. 241).

Teoksen toimitustyö ansaitsee kiitoksen. Artikkelit ovat selkeästi ja ymmärrettävästi kirjoitettuja, minkä ansiosta hankalammatkin teoriat avautuvat lukijalle. Artikkelikokoelmista jää monesti kaipaamaan yhteenvedon tekevää lopetuslukua. Nyt asia on ratkaistu tyylikkäästi Petri Ylikosken kirjoittamalla "Mielen haaste"-luvulla, jossa hän pohtii laajemmin mielen asemaa yhteiskuntatieteissä ja kommentoi kirjan muita artikkeleita. Lukijaystävällinen teko on myös lukujen loppuun sijoitetut "perehtymistä varten" -osiot, joiden kautta aiheesta kiinnostuneet pääsevät tutustumaan jatkotutkimuksiin. On huomattava, että selkeydestään huolimatta kokoelmaa ei ole tarkoitettu alkeisoppikirjaksi. Kirja avautuu paremmin niille, joilla on jo pohjatietoja kognitiivisesta lähestymistavasta. Alaa tuntemattomien kulttuurinja perinteentutkijoiden kannattaakin ottaa oheislukemistoksi johdantoteoksia (esim. Ketola, Pyysiäinen \& Sjöblom 2008; Kronenfeld et al. 2011) sekä kulttuuriantropologian, folkloristiikan ja uskontotieteen väitöskirjoja (esim. Leinonen 2013; Stark 2011; Närhi 2009).

Pidän Ihmismielen sosiaalisuus -teosta ennen kaikkea merkittävänä teoreettisena avauksena suomalaisille yhteiskuntatieteille. Silti jäin teoksen luettuani nälkäiseksi: kirja tuntuu nyt 
tukevalta brunssilta maittavaa päivällistä odotellessa. Toivottavasti teos saakin tulevaisuudessa jatko-osan, jossa kognitiivisesta lähestymistavasta kiinnostuneet yhteiskuntatieteilijät syventyvät aiheeseen empiiristen tutkimusesimerkkiensä kautta.

\section{Kirjallisuus}

Bloch, Maurice 2012: Anthropology and the Cognitive Challenge. Cambridge: Cambridge University Press.

Fingerroos, Outi 2014: Vaihtoehtoja etnisyyden ja diasporan käsitteille. Kirja-arvio. - Elore

21 (1) [online] < http://www.elore.fi/vaihtoehtoja-etnisyyden-ja-diasporan-kasitteille/ $>$ [1.3.2018]

Hutchins, Edwin 1995: Cognition in the Wild. Cambridge, MA: MIT Press.

Kaivola-Bregenhøj, Annika 1988: Kertomus ja kerronta. Helsinki: SKS.

Ketola, Kimmo, Ilkka Pyysiäinen \& Tom Sjöblom (toim.) 2008: Uskonto ja ihmismieli. Helsinki: Gaudeamus.

Kronenfeld, David B., Giovanni Bennardo, Victor C. de Munck \& Michael D. Fischer (eds.) 2011: A Companion to Cognitive Anthropology. Chichester, West Sussex; Walden, MA: Wiley-Blackwell.

Leinonen, Riitta-Marja 2013: Palvelijasta terapeutiksi. Ihmisen ja hevosen suhteen muuttuvat kulttuuriset mallit Suomessa. Oulu: Oulun yliopisto.

Närhi, Jani 2009: Honey Flows Through Fertile Valleys. The Cognitive and Evolutionary Foundations of Paradise Representations. Helsinki: University of Helsinki.

Siikala, Anna-Leena 1984: Tarina ja tulkinta. Tutkimus kansankertojista. Helsinki: SKS.

Sperber, Dan 1996: Explaining Culture. A Naturalistic Approach. Oxford: Blackwell Publishers.

Stark, Eija 2011: Köyhyyden perintö. Tutkimus kulttuurisen tiedon sisällöistä ja jatkuvuuksista suomalaisissa elämänkerta-ja sananlaskuaineistoissa. Helsinki: SKS.

Sørensen, Jesper 2011: Past Minds: Present Historiography and Cognitive Science. - Luther H. Martin \& Jesper Sørensen (eds.), Past Minds. Studies in Cognitive Historiography. London, Oakville, CT: Equinox Pub. Ltd, 179-196.

Filosofian maisteri Konsta Kajander on etnologian ja antropologian tohtorikoulutettava Jyväskylän yliopistossa. 